Institut für Makroökonomie und Konjunkturforschung Macroeconomic Policy Institute

\title{
Keynesian, Classical and New Keynesian Approaches to Fiscal Policy: Comparison and Critique
}

\begin{abstract}
The short-run macroeconomic effectiveness of fiscal policy depends on the effect of policy on AD and the effect of AD on output. This paper examines how macroeconomic perspectives (Keynesian, Post Keynesian, monetarist, classical, new classical, and new Keynesian) describe the effect of $A D$ on output, thereby making or denying space for fiscal policy to impact output. The neo-Ricardian hypothesis $(\mathrm{NRH})$ concerns the effect of bond financed deficits on $A D$. The $\mathrm{NRH}$ turns on the microeconomic behavior of households and can therefore hold in principle in both classical and Keynesian models. Recent new Keynesian arguments about fiscal policy being effective at the zero lower bound represent another capital market imperfection critique of the $\mathrm{NRH}$.
\end{abstract}

Keywords: Fiscal policy, Keynesian, Post Keynesian, monetarist, classical, new Keynesian, neo-Ricardian hypothesis, zero lower bound.

JEL ref.: E6, E62, H3

\footnotetext{
* New America Foundation, Washington DC, Mail@thomaspalley.com
} 


\title{
Keynesian, Classical and New Keynesian Approaches to Fiscal Policy: Comparison and Critique
}

\begin{abstract}
The short-run macroeconomic effectiveness of fiscal policy depends on the effect of policy on $\mathrm{AD}$ and the effect of $\mathrm{AD}$ on output. This paper examines how macroeconomic perspectives (Keynesian, Post Keynesian, monetarist, classical, new classical, and new Keynesian) describe the effect of AD on output, thereby making or denying space for fiscal policy to impact output. The neo-Ricardian hypothesis (NRH) concerns the effect of bond financed deficits on AD. The NRH turns on the microeconomic behavior of households and can therefore hold in principle in both classical and Keynesian models. Recent new Keynesian arguments about fiscal policy being effective at the zero lower bound represent another capital market imperfection critique of the NRH.
\end{abstract}

Keywords: Fiscal policy, Keynesian, Post Keynesian, monetarist, classical, new Keynesian, neo-Ricardian hypothesis, zero lower bound.

JEL ref.: E6, E62, H3.

\section{The revival of debate over fiscal policy}

The financial crisis of 2008 and the accompanying Great Recession saw a widespread turn to fiscal policy by many governments. Confronted by an unprecedentedly abrupt fall of aggregate demand at the end of the third quarter of 2008, governments turned to emergency tax cuts, targeted subsidies, and increased government spending to support aggregate demand (AD) and shore-up economic activity. These policy actions were exemplified by the American Recovery and Reinvestment Act (2009), and measures that were similar in intent were also enacted globally, from China to Germany.

These policies were immediately contested by some economists, particularly those associated with the new classical and real business cycle schools of macroeconomics, who questioned the magnitude of the putative fiscal policy multipliers. Since then, controversy has expanded into other areas. The combination of fiscal stimulus 
measures, reduced tax revenues caused by the recession, and the cost of rescuing financial systems have caused large budget deficits that have added to public debt. Given slow recovery and growth of GDP, that has worsened debt-to-GDP ratios, which in many instances were already subject to negative trends. This has triggered a second stage debate about the sustainability of public sector debt and the possibility of public sector financial crises. This second stage controversy was initiated by Reinhart and Rogoff (2009) in their book This Time is Different: Eight Centuries of Financial Folly. Their claim is economies experience significant growth slowdowns once the public debt to GDP ratio crosses a ninety percent threshold.

The current paper focuses on the stage I debate regarding the short-run macroeconomic effectiveness of fiscal policy. Figure 1 shows the issue of effectiveness involves two steps. Step 1 concerns the effect of fiscal policy on AD, while step 2 concerns the effect of $\mathrm{AD}$ on the real economy. The current paper examines how rival macroeconomic perspectives (neo-Keynesian, Post Keynesian, monetarist, classical, new classical, and new Keynesian) describe the economic effects of changes in $\mathrm{AD}$, thereby making or denying space for fiscal policy to impact economic activity. 
Figure 1. The debate over fiscal policy effectivenss.

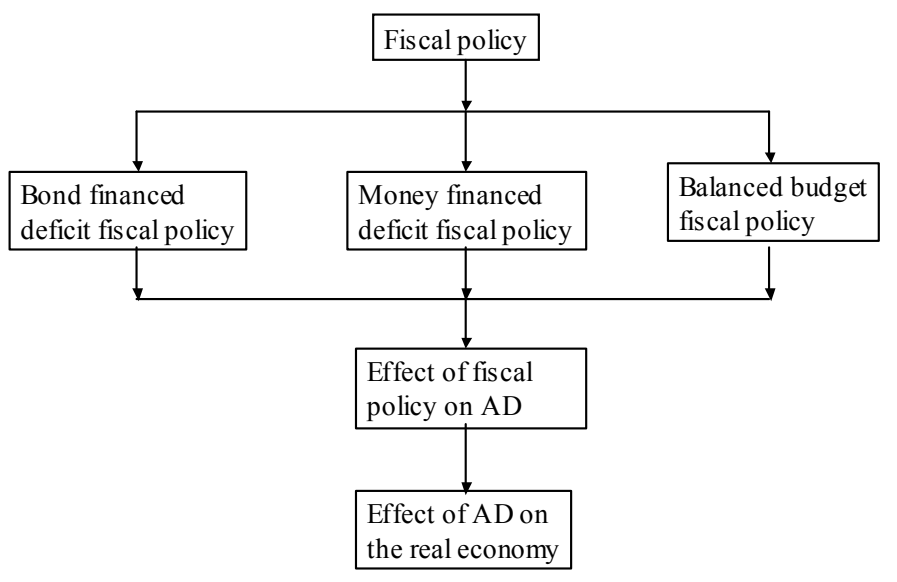

Though step 2 is the primary focus of the paper, step 1 is also of significance because fiscal policy will be ineffective if it has no impact on $\mathrm{AD}$. That raises the issue of the neo-Ricardian hypothesis (NRH) which has dominated debate about the effectiveness of bond financed deficits for the past thirty years. The NRH rests on a particular microeconomic theory of household saving and bequest behavior and it questions the $\mathrm{AD}$ effects of bond financed fiscal policy. Since it is a microeconomic theory it can hold in both classical and Keynesian models - though Keynesians tend to reject it.

The principle conclusion of the paper is short run effectiveness of fiscal policy turns on the theoretical model of the macro economy that is adopted. That is because fiscal policy works through $\mathrm{AD}$, and the impact of $\mathrm{AD}$ on the real economy depends on macroeconomic perspective. The implication is the fiscal policy debate is ultimately a debate over macroeconomic theory. No theoretical paradigm is completely satisfying. Comparison of paradigms spotlights the critical assumptions each makes; provides a better basis of understanding; and can help guide and improve policy. This speaks to the 
need for pluralism in economics and ideas should only be rejected once they are convincingly disproved.

\section{Some theoretical preliminaries}

A major difficulty assessing the debate over fiscal policy effectiveness is the complexity of the issue. A first difficulty is analysis of fiscal policy depends on the theoretical description of the economy in which policy operates. That makes both microeconomic and macroeconomic theory relevant. A second difficulty is the analysis of fiscal policy also depends on the time frame, with longer run analyses introducing additional complications associated with changing real and financial asset stocks. These complexities necessitate some theoretical preliminaries to frame the discussion and define its scope.

\section{II.(a) Microeconomic channels of fiscal policy}

The analysis of fiscal policy is usually identified with macroeconomics, but fiscal policy also has microeconomic channels of effect via the responses of individual agents to policy. These channels provide additional avenues for fiscal policy to have both aggregate demand and supply effects, though such effects are second-order and distinct from first-order macroeconomic effects. Given the emphasis on so-called "micro founded" macro models over the past three decades, these micro channels have gained increasing attention. That has fractured the conversation and distracted attention from the more fundamental issue of macroeconomic impacts of fiscal policy.

With regard to government spending there are two principal microeconomic channels. The first channel concerns government expenditure on public capital and it operates via the production function. If public capital enters the aggregate production 
function, additions to public capital (i.e. public investment expenditure) can impact private sector employment and investment expenditures, with the direction impact depending on the sign of cross partial derivatives of the production function. ${ }^{1}$

The second channel is via household consumption choices and it operates through the utility function. If government spending is a complement to household consumption it will increase private consumption spending, and if it is a substitute it will decrease private consumption spending. ${ }^{2}$ To isolate these microeconomic effects and identify the pure macroeconomic effects, it is assumed that government expenditure does not enter household utility functions and public capital has no impact on private sector productivity.

Taxes also have important microeconomic impacts via their impact on relative prices and incomes, and it also matters whether tax changes are temporary or permanent. These microeconomic tax incentive effects impact both business and households. With

${ }^{1}$ Consider the following aggregate production function $\mathrm{Y}=\mathrm{f}\left(\mathrm{L}, \mathrm{K}_{\mathrm{P}}, \mathrm{K}_{\mathrm{G}}\right)$ where $\mathrm{Y}=$ output, $\mathrm{L}=$ employment, $\mathrm{K}_{\mathrm{P}}=$ stock of private capital, $\mathrm{K}_{\mathrm{G}}=$ stock of public capital. The first partial derivatives of the production function are positive and the second partial derivatives are negative. If public capital is a complement to private capital it has a positive impact on private capital and labor (positive cross-partial derivative) that will induce firms to increase employment, private investment spending, and private capital. If public capital is a substitute for private capital (negative cross-partial derivatives) then the effect will work in the opposite direction. There exists a long-standing empirical literature on this (Aschauer, 1989; Munnell, 1990; Bhatta and Drennan, 2003) that finds the effect of public capital on private sector productivity is positive though the magnitude is subject to dispute.

${ }^{2}$ Let the utility function of consumers be given by $\mathrm{V}=\mathrm{U}(\mathrm{C}, \mathrm{G})$ where $\mathrm{C}=$ consumption of private goods, $\mathrm{G}=$ consumption of government provided public goods. Government spending on public goods therefore yields private utility. First partial derivatives of $U$ with respect to $C$ and $G$ are positive, while second partial derivatives are negative. If the cross-partial is positive then private consumption and public goods are complements and increases in public goods provision will increase demand for private goods. That adds an extra degree of demand stimulus to current government expenditures. If the cross-partial is negative then private consumption and public goods are substitutes and increases in public goods provision will decrease demand for private goods. That reduces the demand stimulus from current government expenditures. If government purchases affect the marginal utility of consumption they may also affect the supply of labor and thereby have a second-order impact on aggregate supply. According to neo-classical theory if the marginal utility of consumption increases households will want to increase labor supply to earn more income to purchase additional consumption goods. The reverse holds if government purchases lower the marginal utility of consumption. 
regard to households, these tax effects depend on whether tax changes are targeted at liquidity constrained, rich, or poor households, because marginal propensities to consume vary by household type. To isolate and identify the pure macroeconomic effects of taxes it is assumed all taxes are lump-sum so that they have no allocation or incentive effects and are a "pure" tax that only affects income.

\section{II.(b) The neo-Ricardian hypothesis (NRH)}

Consideration of the microeconomic channels of fiscal policy leads to the NRH (Barro, 1974) that has dominated much of the debate surrounding fiscal policy effectiveness over the past thirty years. The policy message of the NRH is that bond financed fiscal policy (particularly tax cuts) is likely to be relatively ineffective. ${ }^{3}$

In terms of Figure 1, the NRH questions the impact of bond financed fiscal policy on AD. The central assumption of the $\mathrm{NRH}$ is households internalize future tax obligations associated with bond financing. The theoretical novelty in Barro's (1974) analysis concerns the manner in which households recognize distant future tax obligations. This is done through an inter-generational utility function whereby the utility function of the current generation contains as an argument the expected utility of the next generation.

The critical point is the NRH is at heart a microeconomic theory of household bequest making. Though widely identified with new classical macroeconomics because new classical economists tend to support it, the $\mathrm{NRH}$ is in fact fully compatible with Keynesian macroeconomics. That is because the NRH rests on microeconomic theory

\footnotetext{
${ }^{3}$ Barro's (1974) NRH can be viewed as the fiscal policy twin of the Friedman (1968) - Lucas (1973) natural rate hypothesis that claims anticipated monetary policy is ineffective. The NRH undermines the link between bond financed deficits and $\mathrm{AD}$, whereas the natural rate hypothesis denies systematic effects of monetary policy induced changes of AD on output.
} 
and if households behave in the manner claimed, it will also hold in Keynesian macro models. Moreover, even if the full set of necessary assumptions is not met, bond financed tax cuts and government purchases will tend to have significantly diminished AD effects to the extent households engage in offset saving to pay some part of the implied future tax obligations that are of equal present value to the bond financed stimulus.

The NRH rests on a theory of bequests rooted in its inter-generational formulation of utility. The essential theoretical issue is the coherence and plausibility of the underlying theory of bequests. That means critique of the NRH is an issue of microeconomic theory rather than macroeconomic theory and its limitations are therefore not addressed in the current paper.

\section{II.(c) Time horizons and financing of fiscal policy}

Fiscal policy has effects which may vary by time horizon so that analysis of fiscal policy requires distinguishing between short-run, medium-run, and long-run effects. Short- and medium-run analysis examines the effects of policy under the assumption of unchanged potential output. The assumption is technology, the capital stock, and the labor force is unchanged. The analytical focus is whether fiscal policy moves the economy closer toward full employment, and also how it might change the composition of output.

The distinction between short- and medium-run concerns the effects of changes in financial asset stocks caused by budget deficits. Since budget deficits must be financed, that leads to the creation of financial assets. Medium-run analysis takes account of the impact of changes in financial stocks, which makes the issue of how the budget deficit is financed of critical significance. That is because the method of financing has implications 
for changes in the stock of bonds and money. Concern with the financial asset stock effects of budget deficits was first raised systematically by Christ (1968) and Blinder and Solow (1973), and it was a focus of much of the work of Tobin (Tobin, 1961, 1969, 1982; Tobin and Buiter, 1976, 1980) on financial crowding-out. More recently, it has been raised by Godley and Lavoie (2007). These issues are at the center of the stage II debate about budget deficits and public debt.

Lastly, long-run analysis examines the impacts of fiscal policy on an economy's rate of growth over time. It therefore allows technology, the capital stock and the labor force to change.

Given the paper's focus on the short-run effects of fiscal policy, it abstracts from both medium-run concerns with changing stocks of financial assets and long-run concerns regarding growth. That said, it is not possible to entirely abstract from the financial asset stock effects of fiscal policy because how policy is financed matters for its immediate impact on AD.

These short-run financing effects can be understood via the so-called government budget constraint given by

(1) $\mathrm{G}-\mathrm{T}=\Delta \mathrm{H}+\Delta \mathrm{B}$ $\mathrm{G}=$ government purchases, $\mathrm{T}=$ taxes and transfers, $\mathrm{H}=$ monetary base, and $\mathrm{B}=$ stock of government debt. Budget deficits must be financed, causing immediate changes in the stock (supply) of financial assets that potentially have macroeconomic consequences via interest rates, asset prices, and wealth effects.

Money financed deficits can be financed directly or indirectly $(\Delta H>0, \Delta B=0)$. Direct money financing has the central bank simply crediting the government's bank 
account with new money to cover its spending. Indirect money financing has the central bank financing the government deficit by buying bonds. That process injects money into private bank accounts by paying private bond sellers who had previously purchased the bonds from the government. Such indirect financing has effectively transpired under the Federal Reserve's quantitative easing operations that have had it buy bonds on the secondary market. $^{4}$

Money financing may be by agreement with the central bank or it may also be an induced consequence of monetary policy. Since central banks target interest rates, budget deficits may compel them to conduct expansionary open market operations and buy bonds to prevent rates from rising. Such interest rate stabilizing bond purchases implicitly money finance budget deficits and reveal how fiscal policy is connected inseparably to monetary policy under current policy arrangements. This connection makes it difficult to talk of pure bond financed fiscal policy since if the central bank maintains its target interest rate it will accommodate changes in reserve demand caused by the Treasury's bond financing operations. In a world of interest rate targeting there is automatically some monetary accommodation and some implicit money financing of deficits.

\section{II.(d) Macroeconomic preliminaries}

The final issue, which is a prelude to the main body of the paper, concerns the macroeconomic framework used to describe the economy. This is ground-zero for the debate over fiscal policy effectiveness as the choice of theory determines whether there is

\footnotetext{
${ }^{4}$ In public discussion issuing money is often referred to as "printing money" but the reality is the central bank simply makes electronic book entries that either credit the government's account with the central bank or the accounts of commercial banks with the central bank. In both operations the central bank issues high powered money to cover the deficit.
} 
room for an output response to policy induced changes in AD. Moreover, the issue is relevant for fiscal policy analysis over all time horizons - short, medium, or long.

Classical macroeconomics describes the economy as being at full employment and without excess capacity. Output $(\mathrm{Y})$ is equal to potential output $\left(\mathrm{Y}^{*}\right)$ and demand $(\mathrm{D})$ is brought into alignment with supply by a combination of adjustment of nominal wages, prices, and interest rates (real and nominal) so that $\mathrm{Y}=\mathrm{Y}^{*}=\mathrm{D}$.

Keynesian economics describes the economy as being below full employment and with excess capacity for most of the time. Output is equal to demand, which may be considerably less than potential output so that $\mathrm{Y}=\mathrm{D}<\mathrm{Y}^{*}$.

New classical macroeconomics that came to dominate the economics profession in the 1970s is a refinement of classical macroeconomics that incorporates uncertainty (albeit modeled in probabilistic terms) and rational expectations. The economy is represented as operating at potential output unless subject to unanticipated shocks and policy disturbances. The emphasis on expectations leads to formulation of policy discussions in terms of policy rules and policy anticipations, and the issue of policy effectiveness is framed in terms of the effectiveness of anticipated systematic policy. This introduces some additional insights that are important for all paradigms. However, the fundamental conclusions of new classical macroeconomics are essentially those of classical macroeconomics. Indeed, the classical model corresponds to the new classical model under conditions of perfect foresight. For these reasons, when it comes to the debate over fiscal policy effectiveness the classical and new classical models can essentially be viewed as one. 
The past twenty-five years have also seen the emergence of another body of analysis referred to as "new Keynesian" economics. The essential features are the incorporation of imperfect competition and price-stickiness into the new classical model.

The complexity of the debate over fiscal policy is captured in Figure 2. Even after ruling out medium run asset stock effects and microeconomic effects (tax distortions and government spending in the utility and production functions) there remain numerous analytical issues to control for. First and foremost, is the macroeconomic perspective neo-Keynesian, Keynesian and Post Keynesian, monetarist, classical, new classical and new Keynesian. Second, there is the question of money versus bond financed fiscal policy. Third, there is the question of tax or government spending based fiscal policy. Fourth, there is the question of whether or not the NRH holds. That generates a $2 \times 4$ matrix for each macroeconomic perspective, of which there are six. For every cell (of which there are eight) there is the question of the direction of change of real output $(\Delta y)$, the price level $(\Delta \mathrm{p})$, the nominal interest rate $(\Delta \mathrm{i})$, the nominal wage $(\Delta \mathrm{w})$, and the real wage $(\Delta(\mathrm{w} / \mathrm{p}))$. Employment is assumed to change in the same direction as output. Moreover, this abstracts from the issue of inflation which is taken as constant so that the real interest rate is assumed to move in the same direction as the nominal interest rate. This multiplicity of macroeconomic perspectives, combined with the number of issue at stake, goes a long way to explaining the contention and cross-talk surrounding fiscal policy. 
Figure 2. The complexity of the theoretical debate regarding the short run economics of fiscal policy.

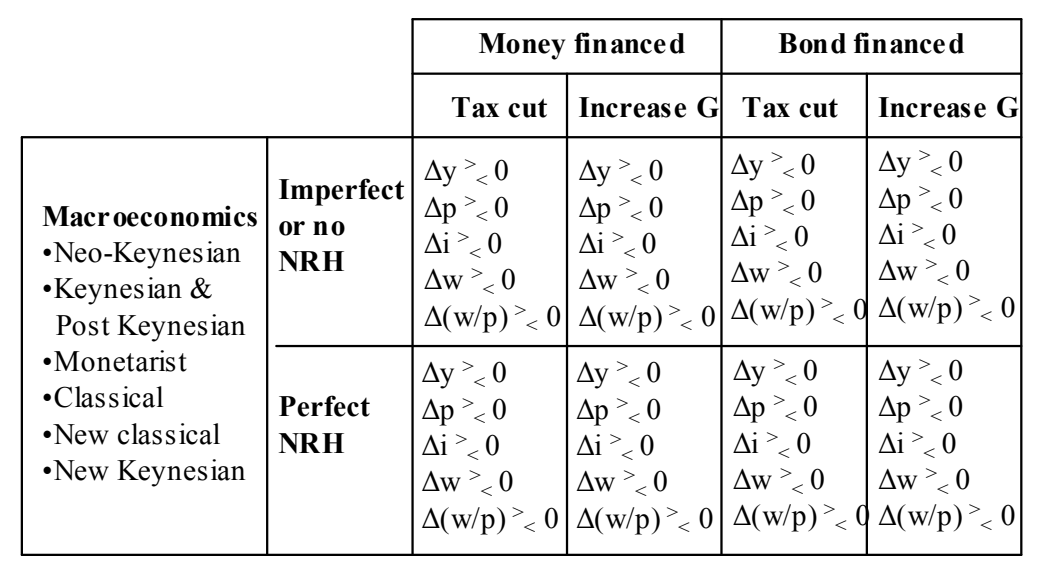

Though macroeconomic perspectives differ in their assessment of fiscal policy, they share three propositions regarding its impact on AD:

Proposition 1: In all macroeconomic perspectives money financed fiscal policy is always at least or more powerful with respect to $\mathrm{AD}$ than bond financed fiscal policy. With money financed policy the public ends up with extra money in its hands. With bond financed policy the public ends up with extra bonds in its hands. Extra money tends to be more expansionary because people can spend it directly via a monetarist channel (Palley, 1997) or buy other assets, lowering interest rates and raising wealth values (Tobin, 1969, 1982). Conversely, bonds must be sold and converted into money before they can finance consumption or other asset purchases, which can raise bond interest rates.

Proposition 2: In all perspectives government spending is at least or more powerful with respect to $\mathrm{AD}$ than tax based fiscal policy. That is because each unit of government spending adds a full unit to AD whereas tax cuts work through the filter of consumption spending and some or all of the cut may be saved. 
Proposition 3: In all perspectives, bond financed fiscal policy is more powerful with regard to $\mathrm{AD}$ the more the necessary assumptions of the $\mathrm{NRH}$ are violated. The more the $\mathrm{NRH}$ is violated, the more government bonds represent net wealth in the sense of expanding the budget constraint and consumption possibility set. Though the addition to net wealth may be less than the full face value of bonds, the addition is more positive the more the NRH is violated.

\section{Macroeconomic perspectives and the short-run effects of fiscal policy}

This section examines the short-run effectiveness of fiscal policy within six different macroeconomic theoretical perspectives. To avoid conflation with microeconomic arguments it assumes lump-sum taxes; government purchases have no effect on the aggregate production function; and government purchases generate no household utility. These assumptions enable a focus on the first-order aspects of the fiscal policy debate which is about the effect of policy on $\mathrm{AD}$ and the effect of $\mathrm{AD}$ on output.

\section{III.A The neo-Keynesian model}

The starting point of the analysis is the neo-Keynesian ISLM model which, though criticized by all perspectives, remains a bridge between all perspectives. Figure 3 shows the conventional IS-LM and AS-AD diagrams. Bond financed tax cuts shift the IS schedule left and $\mathrm{AD}$ schedule right because tax cuts add to $\mathrm{AD}$, as does the wealth effect generated by bond financing. Output, the interest rate, and the price level increase ( $\Delta y>$ $0, \Delta \mathrm{i}>0, \Delta \mathrm{p}>0)$. The increase in the interest rate diminishes the effect of fiscal policy and is at the core of the debate about financial crowding-out (Tobin and Buiter, 1976). ${ }^{5}$ Given the neo-Keynesian assumption of fixed nominal wages, the real wage falls $(\Delta \mathrm{w}=$

\footnotetext{
${ }^{5}$ The financial crowding-out debate also constitutes a point of entry for medium-term concerns about financial stock effects and sustainability of deficit financed fiscal policy.
} 
$0, \Delta(\mathrm{w} / \mathrm{p})<0)$. In the labor market, the assumption is the economy is on the labor demand schedule (marginal product of labor), but it is off the aggregate labor supply schedule so that workers are available to support increased output despite the fact the real wage falls. Given proposition 2, all of these effects are larger if fiscal policy takes the form of bond financed government spending as this generates larger shifts of the IS and AD schedules.

Figure 3. The IS-LM and AS-AD diagrams for the neoKeynesian model

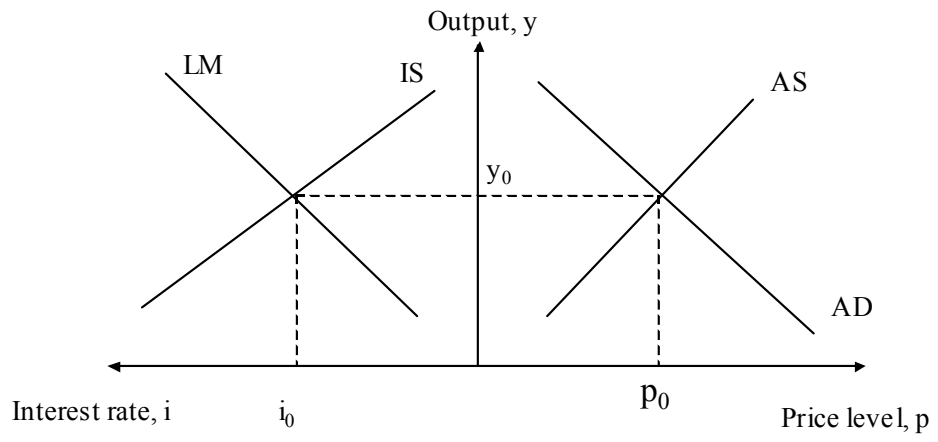

If fiscal policy is money financed the LM schedule also shifts left. Given proposition 1, the impact on $\mathrm{AD}$ is larger so that output and the price level rise by more and the real wage falls by more. However, the interest rate rises by less and may even fall.

The NRH is a microeconomic theory about household behavior, which means it can also hold in Keynesian macro models. However, it is only relevant for bond financed fiscal policy and the effects of money financed fiscal policy are unchanged. In this case, bond financed tax cuts now have no impact on the IS or AD schedules because 
households save all the tax cut. With regard to bond financed government spending, it still has a positive impact on the IS and AD schedules, but the impact is smaller because households increase their saving in anticipation of future tax increases to pay for the costs of government debt. ${ }^{6}$ Note, the less that households are bound by the NRH, the less it will bite. From proposition 3, if the NRH holds imperfectly, bond financed tax cuts will start having an effect on $\mathrm{AD}$ and output and the effect of bond financed spending will increase. Table A.1 in the appendix provides full signing of the short run effects of fiscal policy in the neo-Keynesian model.

\section{III.B The Post Keynesian model}

Figure 4 shows the IS-LM and AS-AD diagrams for a Post Keynesian economy. The figure captures the principal predictions of the Post Keynesian perspectives, though the underlying microeconomic logic is different. ${ }^{7}$ The LM schedule is horizontal reflecting the fact that central banks always set the market interest rate and must support whatever money supply the banking system generates. The AS schedule is also horizontal reflecting Kaleckian pricing behavior whereby firms set prices as a mark-up over normal average costs and meet all demand at that price.

\footnotetext{
${ }^{6}$ Under the NRH bond financed lump sum tax cuts have zero impact on AD. However, bond financed government spending still has a positive impact. It adds immediately to $\mathrm{AD}$. It also implies future taxes that shrink the inter-temporal net present value budget constraint by an amount equal to the increase in government spending. That causes reduced net present value consumption across all generations equal to the increase in G. Since the current generation only contributes part of this reduction, there is a net increase in $\mathrm{AD}$. If the current generation gets utility from increased $\mathrm{G}$ it would reduce its consumption by more and increase its bequest saving to equalize inter-generational marginal utility.

${ }^{7}$ Post Keynesians explain the horizontal LM in terms of the theory of endogenous credit money (Moore, 1988), whereas neo-Keynesians rationalize it in terms of the monetary authority selecting a nominal interest rate target operating procedure. If the monetary authority has a "lean against the wind" interest rate reaction function then the LM will be positively sloped. Additionally, Post Keynesians argue the AD schedule may be positively sloped in price - output space owing to inside debt effects (Dutt, 1986/7).
} 
Figure 4. The IS-LM and AS-AD diagrams for the Post-

Keynesian model.

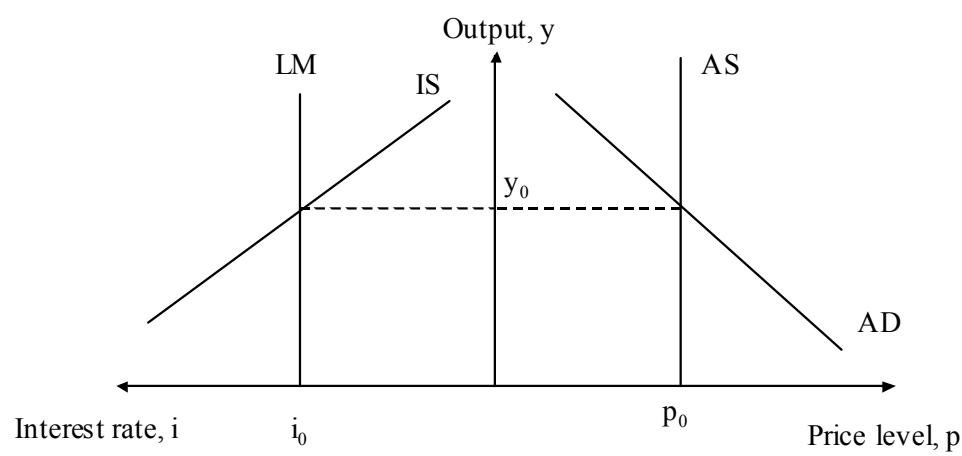

Bond financed tax cuts shift the IS schedule left and the AD schedule right. Output increases $(\Delta \mathrm{y}>0)$ but the interest rate and price level are unchanged $(\Delta \mathrm{i}=\Delta \mathrm{p}=$ $0)$, as are the nominal and real wage $(\Delta \mathrm{w}=\Delta(\mathrm{w} / \mathrm{p})=0)$. Proposition 2 again implies that bond financed government spending has a larger expansionary effect because of its larger multiplier.

An interesting feature about the Post Keynesian model is that the sharp distinction between bond and money financing disappears. To understand this proposition, consider an initial money financed tax cut. That increases the supply of reserves, putting incipient downward pressure on the interest rate. The monetary authority must then conduct defensive open market operations that partially drain those reserves in order to maintain its interest rate target. However, once income, bank lending and the demand for transactions balances starts increasing the monetary authority must provide additional reserves via open market operations both to maintain its interest rate target and ensure banking sector solvency in face of increased banking sector activity. Judged from the 
position of ultimate balance sheets, the fiscal action is a mix of money and bond financing. The ultimate mix depends on how much banking system activity increases, and fiscal policy will be more money financed the larger the increase in banking activity. This proposition reflects the logic of the theory of endogenous money which holds the money supply is determined by the banking system. That means fiscal policy cannot increase the money supply without regard to the banking system's needs, and the ultimate increase in the money supply depends on how much fiscal policy stimulates increased banking sector activity.

Though in practice no Post Keynesians adhere to the NRH, it is again in principle compatible with the Post Keynesian macro model because it is a microeconomic hypothesis about household behavior. ${ }^{8}$ If the pure NRH holds, bond financed tax cuts have no impact in the Post Keynesian model because the tax cut is fully saved. Consequently, the IS and AD schedules never shift and banking system activity does not increase. However, bond financed spending stimulates some additional activity as households only partially offset the implied future tax increase to ensure some of it is borne by future generations. Proposition 3 again implies bond financed fiscal policy will have a greater effect the more the assumptions of the NRH are violated. Table A.2 in the appendix provides the full signings with regard to deficit financed fiscal policy in the Post Keynesian model under alternative assumptions.

\footnotetext{
${ }^{8}$ As shown in section II.(b) the NRH is ultimately a theory of bequest giving. The fact that Post Keynesians reject the NRH leaves open the question of bequests and their implications for Post Keynesian analysis of fiscal policy.
} 


\section{III.C The monetarist model}

Debate over the short-run effectiveness of fiscal policy has a long history in macroeconomics, and the modern debate can be viewed as being launched by Milton Friedman's (1970) monetarism. ${ }^{9}$ Monetarism is now largely a historical curiosity. Among Post Keynesians it is discredited for its assumption of an exogenous money supply, and among new classicals it is discredited for its lack of attention to the supply-side of the economy and its violation of the axiom of money neutrality. That said, despite its intellectual weakness, monetarism is of great significance in the history of thought because it marked the beginning of the over-throw of the neo-Keynesian consensus and because of the questions it planted regarding the efficacy of fiscal policy.

The monetarist critique of fiscal policy is summarized in the aphorism "Money is all that matters", and the critique is represented in Figure 5. In the monetarist model output is determined according to the Fisher equation given by

(2) $\mathrm{Y}=\mathrm{MV} / \mathrm{P}$

$\mathrm{V}=$ velocity of money. Within the model money and bonds are both net wealth. Bond financed fiscal policy (tax cuts or increased government purchases) shifts the IS left but the $\mathrm{LM}$ and $\mathrm{AD}$ schedules are unchanged. Consequently, output, the price level, the nominal wage, and the real wage are all unchanged $(\Delta \mathrm{y}=\Delta \mathrm{p}=\Delta \mathrm{w}=\Delta(\mathrm{w} / \mathrm{p})=0)$. However, the nominal interest rate rises $(\Delta \mathrm{i}>0)$. Bond financed fiscal policy is therefore

\footnotetext{
${ }^{9}$ Friedman (1961) had a second critique that focused on the problem of implementation lags. One problem concerned "inside" time lags regarding getting political agreement to pass discretionary fiscal policy. A second problem concerned "outside" time lags regarding the time taken implement policy and the time taken for policy to have full economic effect. This critique was pragmatic rather than theoretical and focused on the ability of fiscal policy to stabilize the economy rather than to affect the economy.
} 
fully crowded out in a manner similar to the 1930s Treasury view associated with the classical macro model (about which more below).

Figure 5. The IS-LM and AS-AD diagrams for the monetarist model

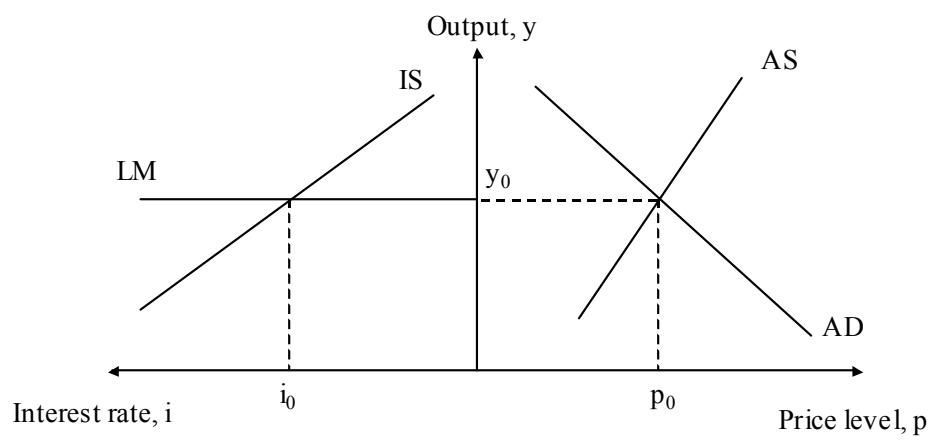

With regard to money financed fiscal policy, it shifts the IS left, the LM up, and the $\mathrm{AD}$ right. Output and the price level therefore increase $(\Delta y>0, \Delta p>0)$; the change in interest rates is ambiguous $\left(\Delta \mathrm{i}^{>}<0\right)$; the nominal wage is constant $(\Delta \mathrm{w}=0)$; and the real wage falls $(\Delta(\mathrm{w} / \mathrm{p})<0)$. The labor market assumptions are the same as the neoKeynesian model: firms are on the labor demand schedule but workers are off the labor supply schedule.

Monetarism therefore accepts the short-run effectiveness of money financed fiscal policy but rejects the effectiveness of bond financed fiscal policy. However, the rejection of bond financed fiscal policy effectiveness is entirely related to the money supply and has nothing to do with either classical (fixed output) or neo-Ricardian (unchanged net wealth and consumption possibilities) arguments. 
These features make monetarism an odd form of Keynesianism. It is Keynesian in the sense that money financed increases in AD generate permanently increased output. However, the economy is subject to a rigid exogenous money collar. That collar means bond financed fiscal policy is completely crowded out, generating a prediction observationally equivalent to the Treasury view associated with the classical macro model. This illustrates monetarism's uneasy status in between Keynesian and classical macroeconomics.

Finally, as with the neo-Keynesian and Post Keynesian macro models, the NRH can also hold in the monetarist macro models. If it does, bond financed tax cuts have no effect at all $(\Delta \mathrm{y}=\Delta \mathrm{i}=\Delta \mathrm{p}=\Delta \mathrm{w}=\Delta(\mathrm{w} / \mathrm{p})=0)$. However, bond financed spending shifts the IS left for reasons discussed earlier so that interest rates rise $(\Delta \mathrm{i}>0)$, but all else is unchanged $(\Delta \mathrm{y}=\Delta \mathrm{p}=\Delta \mathrm{w}=\Delta(\mathrm{w} / \mathrm{p})=0)$. Table A.3 in the appendix provides the full signing of fiscal policy outcomes under alternative assumptions.

\section{III (d) The classical model}

The classical macro model (Sargent, 1979, chapter 1) constitutes the core alternative to the Keynesian model. The key feature about the classical model is output is equal to full employment output, $\mathrm{y}^{*}$. Fiscal policy can therefore affect $\mathrm{AD}$ but $\mathrm{AD}$ cannot affect output. Consequently, any effects of fiscal policy are restricted to operate on the price level (p) and interest rate (i).

The classical model is illustrated in Figure 6, which includes an aggregate production function $(y=f(n))$ and labor market with supply $\left(L^{s}\right)$ and demand schedules. The demand schedule is the marginal product of labor (MPL). Output is fixed at its full employment level, rendering the AS function vertical. The price level and interest rate 
adjust to ensure $\mathrm{AD}$ equals full employment output $\left(\mathrm{y}^{*}\right)$. Figure 6 makes clear the two step process of output and price determination in the classical model. Step 1, involving the bottom half of Figure 6, involves determining the level of labor exchange and production. Step 2, involving the top half of Figure 6, involves determining nominal prices and interest rates consistent with the production and exchange decision. ${ }^{10}$

Bond financed tax cuts shift the IS schedule left and the AD schedule right so that the price level and interest rate riese $(\Delta \mathrm{p}>0, \Delta \mathrm{i}>0)$. The nominal wage rises $(\Delta \mathrm{w}>0)$ to leave the real wage unchanged $(\Delta(\mathrm{w} / \mathrm{p})=0)$, and output is also therefore unchanged $(\Delta \mathrm{y}$ $=0$ ). The exact same logic holds for bond financed government spending, only the shifts of the IS and AD schedule are larger because none of the initial fiscal injection is saved. With output fixed and unresponsive to changes in $\mathrm{AD}$, expansionary fiscal policy has no impact on output and just drives up the price level and interest rate. ${ }^{11}$ However since government expenditure has gone up, private sector absorption (consumption and investment) must decrease so that fiscal policy changes the composition of output. This is the logic of the infamous Treasury view of the 1930s rejecting expansionary fiscal policy - but that logic is conditional on being at full employment output.

\footnotetext{
${ }^{10}$ The logic of the classical model involves two steps. In step 1, given preferences and productivity, agents decide on how much they want to exchange and produce. That determines the level of real output $\left(\mathrm{y}^{*}\right)$, employment, and real wage (w/p). In step 2, given the chosen level of output, employment, and real wage, agents establish the nominal wage, price level and interest rate based on expectations of the money supply. The price level and interest rate are jointly determined to clear both the goods (IS) and money (LM) markets, and the nominal wage is set to deliver the desired real wage given the price level. This logic reflects how the classical model embodies a barter exchange mentality (step 1) on which is imposed a veil of money (step 2). Mathematically speaking, the classical model is block recursive with output determination separated from interest rate and nominal price determination.

${ }^{11}$ According to the classical model, both increased government spending and tax cuts reduce aggregate saving, which drives up interest rates in the loanable funds market. Higher interest rates reduce money demand, causing a higher price level. In an open economy, increased demand can be met by increased imports so that there may be no crowding out and real interest rates can remain unchanged. With interest rates unchanged, money demand will be unchanged and so will the price level. What happens after that depends on the monetary and exchange rate dynamics in response to the resulting trade deficit.
} 
Figure 6. The IS-LM, AS-AD and labor market diagrams for the classical model

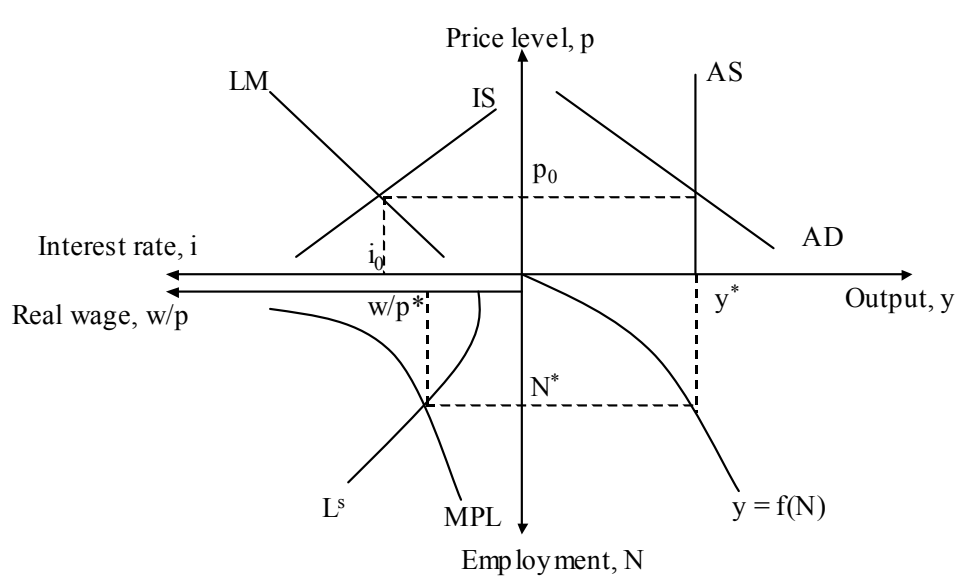

Money financed tax cuts shift the IS left, the LM right, and the AD right. The result is the price level rises $(\Delta p>0)$. The interest rate also rises $(\Delta \mathrm{i}>0)$ because increased $\mathrm{AD}$ necessitates a higher interest rate in the loanable funds market to balance saving and investment. Output and the real wage are unchanged $(\Delta y=\Delta(w / p)=0)$, but the nominal wage rises to leave the real wage unchanged $(\Delta \mathrm{w}>0)$.

Finally, if the NRH holds bond financed tax cuts have no impact on the IS and $\mathrm{AD}$ schedules because the tax cut is entirely saved. Consequently, the price level, interest rate, output, nominal wage and real wage are all unchanged $(\Delta \mathrm{p}=\Delta \mathrm{i}=\Delta \mathrm{y}=\Delta \mathrm{w}=$ $\Delta(\mathrm{w} / \mathrm{p})=0)$. For the same reasons as before, bond financed government spending shifts the IS left and the $\mathrm{AD}$ right so that $\Delta \mathrm{p}>0, \Delta \mathrm{w}>0$, and $\Delta \mathrm{i}>0$, while $\Delta \mathrm{y}=\Delta(\mathrm{w} / \mathrm{p})=0$. From proposition 3, the more the assumptions of the NRH are violated the larger the increase in the price level, nominal wage, and interest rate. Table A.4 in the appendix provides the full signings for fiscal policy in the classical model under alternative assumptions. 


\section{III.(e) The new classical model}

New classical macroeconomics, which superseded monetarism in the 1970s, represents a revival and extension of classical macroeconomics. Like classical macroeconomics, it rejects monetarism by reasserting the neutrality of money. It also extends classical macroeconomics by introducing uncertainty (albeit modeled in probabilistic terms) and rational expectations. Take away uncertainty or replace rational expectations with perfect foresight, and the new classical model becomes identical to the classical model.

The central focus of new classical macroeconomics is uncertainty about economic policy, and monetary policy in particular. This leads to the notion of "surprise policy" that generates "expectation errors". Those errors are temporary because agents learn about them and their cause owing to having rational expectations. However, the errors mean policy can have temporary effects that are not present in the classical macro model. That is the "newness" in new classical macroeconomics.

Surprise policy renders the new classical model superficially more Keynesian as it can generate effects that mimic Keynesian predictions. It also changes the character of the debate. Whereas the Keynesian versus classical policy debate was constructed in terms of "effect versus no effect", the Keynesian - versus new classical policy debate is reconstructed in terms of "permanent versus temporary effects".

The predictions of the new classical model can be understood using Figure 6 describing the classical model. The impacts of expected bond and money financed fiscal policy are identical with the predictions of the classical model discussed in section III.(d) and shown in Table A.4. 
Because monetary policy is somewhat secretive, the notion of surprise monetary policy makes sense. However, because fiscal policy is legislated and more transparent, the notion of surprise fiscal policy makes little sense. Consequently, fiscal policy in the new classical model reduces to fiscal policy in the classical model and it produces "Treasury view" crowding-out.

If surprise fiscal policy were possible, then the predictions would be as follows. Surprise bond financed tax cuts and increased spending both shift the IS left and the AD right so that the price level and interest rates rise $(\Delta \mathrm{p}>0, \Delta \mathrm{i}>0)$. Firms also bid up the nominal wage $(\Delta \mathrm{w}>0)$ and workers supply more labor despite the fact that the real wage falls. They do so because they misinterpret the higher nominal wage as a higher real wage, and this allows output to temporarily increase. In effect, surprise fiscal policy fools them in the same way as does surprise monetary policy. However, once workers realize that real wages have not increased, labor supply falls back, and the real wage and output revert to their initial levels. Once the surprise is understood, all that remains is a higher price level and interest rate, just as in the classical model.

Surprise money financed tax cuts and spending shift the IS left, the LM right, and the AD right. The addition of monetary stimulus causes the AD to shift further than surprise bond financed stimulus. The direction of changes to $y, p, w$ and $w / p$ are the same as with bond financing, but the increases in $\mathrm{y}, \mathrm{p}$ and $\mathrm{w}$ are larger, as is the fall in $\mathrm{w} / \mathrm{p}$. Once, the policy surprise is understood the real wage and output revert back to their initial level, and the continuing effects of policy are the same as in the classical model. 
As with the other paradigms, the NRH can also apply in new classical models. In this case the outcomes with regard to bond financed fiscal policy are again identical with those of the classical model discussed in the previous section.

One final point concerns automatic stabilizer fiscal policy. The new classical model, like the classical model, denies that discretionary monetary and fiscal policy have lasting output effects. Surprise discretionary monetary policy can cause temporary increases in output, as can surprise fiscal policy but those increases reverse once agents become aware of the surprise. However, tax cuts implemented through automatic stabilizer mechanisms can permanently stabilize output (McCallum and Whitaker, 1979). That is because such tax cuts are tied to surprise nominal demand shocks, thereby making tax cuts mimic surprise shocks that cannot be anticipated and offset by agents. In the new classical model surprise nominal demand shocks generate price level shocks and relative price level misperceptions that alter aggregate supply. If tax cuts are tied to the nominal demand shock they serve to offset the shock, thereby preventing it from impacting the price level, relative prices and output. Consequently, tax cuts implemented via automatic stabilizer mechanisms stabilize output and permanently reduce output volatility. That means there is a place for automatic stabilizer fiscal policy in the new classical model. However, fiscal policy must be conditioned on surprises, and there remains no place for non-surprise fiscal policy that seeks to permanently raise output as claimed possible by Keynesian models.

\section{III.(f) The new Keynesian model}

The last two decades have seen the introduction of new Keynesian models (see Rotemberg (1987) for a canonical statement). Though labeled Keynesian, these models 
are better understood as new classical models with the additional assumptions of temporary price rigidity and monopolistic competition. The key assumption is temporary price rigidity, and monopolistic competition is more of an embellishment that justifies the assumption of price rigidity.

Figure 7 illustrates the workings of the new Keynesian model. The southwest quadrant shows the labor market. The only difference from the new classical model is that firms are imperfectly competitive so the marginal product of labor function (MPL) is accompanied by a marginal revenue product of labor schedule (MRPL). Firms choose an employment level where the MRPL equals the real wage (w/p). The south-east quadrant shows a standard concave production function that links employment and output. The logic of employment and output determination is identical to the new classical model. Households and firms decide how much labor to exchange and output to produce based on anticipations of the real wage and recognizing that real wages are set under monopolistically competitive conditions. That determines the long run equilibrium real wage and the natural level of employment $\left(\mathrm{N}^{*}\right)$ and output $\left(\mathrm{y}^{*}\right)$. 
Figure 7. The new Keynesian macro model.

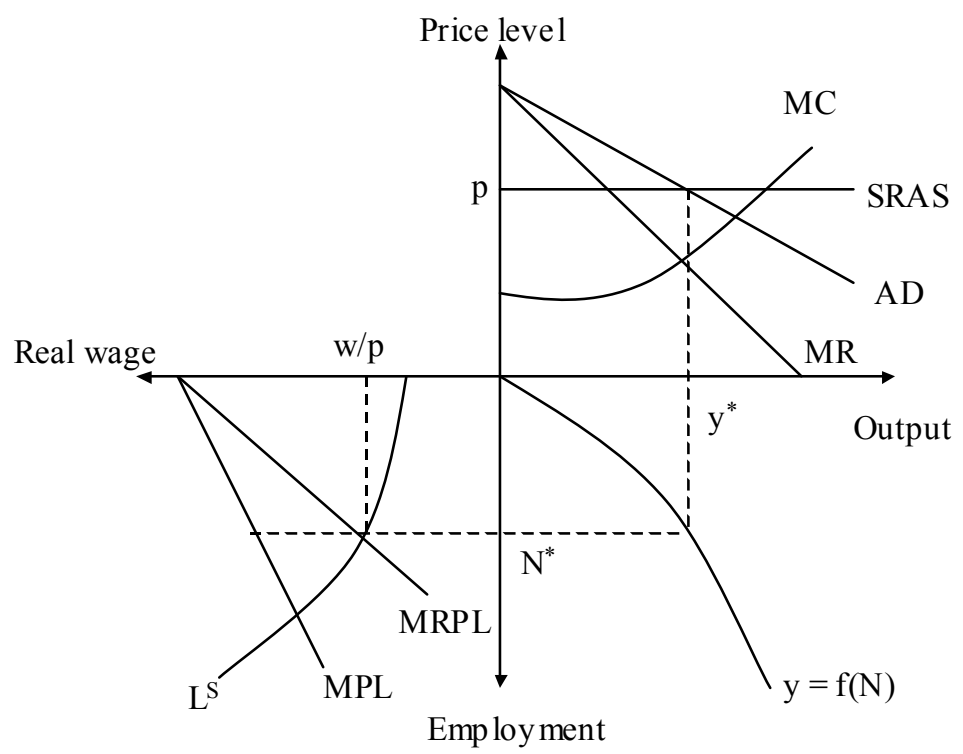

The northeast quadrant shows the goods market which has a standard AD schedule. That AD schedule embodies the monetary authority's interest rate rule. The nominal interest rate remains unchanged along the length of the $\mathrm{AD}$ schedule if the monetary authority has a constant nominal interest rate target. If it has a "leaning against the wind" reaction function the nominal interest rate rises as the economy moves down the $\mathrm{AD}$ schedule. It also implies the $\mathrm{AD}$ schedule is steeper under such a regime. In addition to the $\mathrm{AD}$ schedule there is also a marginal revenue (MR) and marginal cost (MC) schedule. Given the output and employment exchange decision and implied real wage, firms set a price level such that expected demand equals output $\left(\mathrm{y}^{*}\right)$ at which point MR equals MC. Finally, having set prices, firms are bound by rigid prices for the duration of the price adjustment time interval. That generates a horizontal short run 
aggregate supply schedule (SRAS) whereby firms meet all demand at the fixed price for the duration of the price period.

There are several features to note about the model. First, the production and employment logic is identical to the new classical model, the only difference being that firms are monopolistically competitive rather than perfectly competitive. The role of monopolistic competition is to justify better the introduction of rigid prices.

Second, there is a natural level of output and employment to which the economy reverts. Demand shocks between price setting intervals can push the economy along the SRAS, above or below natural output. However, when firms can reset prices they do so such that the economy reverts to natural output.

These mechanics of natural output determination should make clear that the new Keynesian model is essentially the new classical model with the addition of temporary price rigidity. In principle perfectly competitive firms could also be subject to menu costs and prices could be rigid for some period. In that case the new classical model generates near identical outcomes to the new Keynesian model, the difference being natural employment and output would be slightly higher owing to the absence of the distortion associated with imperfect competition. ${ }^{12}$

Third, employment outcomes are always on the labor supply schedule, reflecting the belief that households always maximize utility. If demand increases firms raise their nominal wage to attract more labor and the real wage rises because prices are fixed. If demand falls, firms lower their nominal wage as they need less labor and the real wage

\footnotetext{
${ }^{12}$ The standard new classical macro model has prices flexible and known by firms, whereas workers have pre-determined price expectations. Introducing price rigidity is tantamount to reversing this assignment so that firms now operate with pre-determined price while workers get to see actual prices. Effectively, firms now get "fooled" into supplying more rather than workers being fooled.
} 
falls, again because prices are fixed. The implication is there no Keynesian macroeconomic unemployment (off the labor supply function unemployment) and only frictional microeconomic unemployment. ${ }^{13}$

As with the new classical model, the only type of policy that affects output is surprise policy. Policy that is systematic and anticipated is incorporated into expectations of $\mathrm{AD}$ that determine the initial price level and nominal wage, and it has no impact on output because anticipated policy does not affect the MPL, MRPL, or labor supply function.

The introduction of price rigidity creates a window in which the notion of surprise fiscal policy makes sense. With prices fixed, there is a period when firms cannot respond by changing prices. Surprise bond financed tax cuts shift the AD and MR schedules right. Output and employment increases $(\Delta y>0, \Delta N>0)$; the price level is constant $(\Delta p=0)$; and the nominal and real wage increases $(\Delta \mathrm{w}>0, \Delta(\mathrm{w} / \mathrm{p})>0)$. The change in the interest rate depends on the monetary authority's reaction function, and it will increase $(\Delta \mathrm{i}>0)$ if the monetary authority has a leaning against the wind reaction function - which is the conventional assumption.

Surprise bond financed government spending generates changes of the same sign but the magnitude is larger. That is because government spending has a larger impact on $\mathrm{AD}$ and MR than tax cuts (proposition 2).

Surprise money financed tax cuts and spending increases again shift the AD and MR schedules right, generating the same pattern of changes. By lemma 1, the magnitude

\footnotetext{
13 This point is made by Dullien (2011).
} 
of increase from expansionary money financed fiscal policy is larger than that from bond financed fiscal policy.

The important feature is that all of these results are conditional on prices being fixed. Once firms can reset their prices they take account of the $\mathrm{AD}$ effects of fiscal policy, raise their prices, and move the economy back to the natural level of employment $\left(\mathrm{N}^{*}\right)$ and output $\left(\mathrm{y}^{*}\right) \cdot{ }^{14}$ Unlike Keynesian models, fiscal policy is only temporarily effective and it must be implemented after prices have been set and cannot be adjusted. Fiscal policy will be effective for a short period if price stickiness is of short duration: it will be effective for a longer period if price stickiness is of long duration. If expansionary or contractionary fiscal policy is known about at the time of price setting it will be fully neutralized by higher or lower prices respectively, in accordance with the predictions of the classical and new classical models.

As in the other perspectives examined, the NRH is also consistent with the new Keynesian perspective. Bond financed tax cuts will be fully neutralized as households save the proceeds to offset implied future tax increases, while the effect of bond financed government spending is reduced because agents increase their saving to partially cover implied future tax increases. Money financed fiscal policy is unaffected. Table A.5 in the appendix shows the comparative static predictions for the new Keynesian model.

Finally, following the logic of McCallum and Whittaker (1979), fiscal policy that responds to shocks (i.e. is conditioned on shocks) can also stabilize output in the new Keynesian model by offsetting unanticipated demand shocks.

\footnotetext{
${ }^{14}$ This is most easily understood if all firms reset prices at a common moment. If firms adjust prices at different times surprise policy will generate persistence effects and the reversion to natural output and employment will be gradual.
} 


\section{III.(g) Fiscal policy at the zero lower bound}

Within new Keynesian models bond financed fiscal policy is ineffective in the presence of the NRH. Recently, Christiano et al. (2009) have shown that fiscal policy can be effective despite the $\mathrm{NRH}$ if an economy is stuck at the zero lower bound (ZLB) to nominal interest rates. Their argument is easily understood in terms of capital market failure. The NRH requires perfect capital markets. The ZLB represents a capital market imperfection which causes the NRH to fail.

In new Keynesian models with temporary price stickiness having the interest rate stuck at the ZLB generates a situation where desired saving exceeds investment. Households and firms are therefore constrained in their production and exchange by the level of $\mathrm{AD}$. Consequently, deficit financed tax cuts and government purchases can increase economic activity significantly and the government expenditure multiplier may be large. This holds even if households behave according to the NRH.

The logic is illustrated in Figure 8 which shows $\mathrm{AD}$ as a function of the nominal interest rate. Given the current price level and path of inflation expectations the market clearing nominal interest rate should be $\mathrm{i}_{0}<0$. However, the actual nominal interest rate is stuck at the ZLB, restricting demand to $\mathrm{y}_{0}$. Money financed tax cuts which have no future implied tax obligation, unambiguously shift the AD schedule right and expand output. Bond financed tax cuts also have a similar qualitative effect despite the fact they carry a future implied tax obligation. 
Figure 8. Bond financed fiscal policy in a new classical model with the NRH at the ZLB.

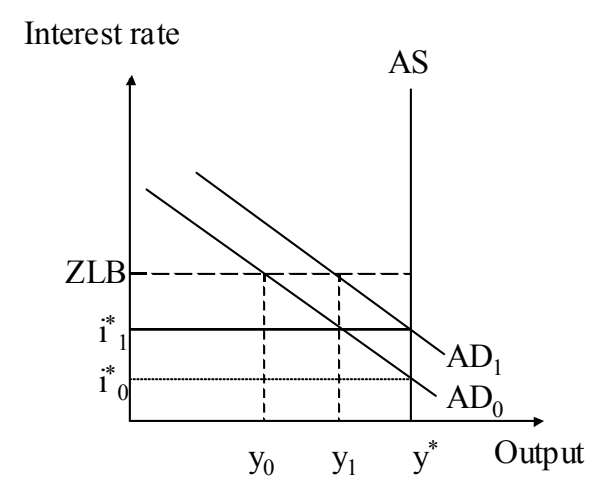

The reason why bond financed tax cuts are expansionary is because the net present value of future tax obligations is less than present value of a current tax cut. The logic is as follows. The current market clearing shadow interest rate is negative $\left(i^{*} 0<0\right)$ and it is also less than the normal market clearing interest rate $\left(i^{*}>0\right)$ that is expected to prevail in the future. Consequently, agents' current discount rate is negative which increases the value of income today. Conversely, their future discount rate is positive and relatively high compared to today which reduces the net present value on future tax obligations. Bond financed fiscal policy that increases disposable income today is therefore valued more than the future implied tax obligation. That means bond financed fiscal policy increases households' net present worth so that AD increases. In effect, the ZLB is a form of capital market imperfection and the NRH always breaks down in the presence of such imperfections.

As shown in Figure 8, bond financed fiscal policy increases AD, which increases the shadow market interest rate $\left(i^{*} 1>i^{*} 0\right)$. When the shadow interest rate equals the 
ZLB the economy reverts to its standard new Keynesian NRH form in which bond financed lump-sum tax cuts have no effect on $\mathrm{AD}$ because the net present value of future implied tax obligations equals the value of the tax cut so that consumption is unchanged. Such reasoning implies means the government expenditure multiplier falls continuously in magnitude as the economy approaches the ZLB. This is because households start saving more to meet future implied tax obligations which are of increasingly greater burden due to the closing of the gap between the current shadow market interest rate and the future normal interest rate.

The reasoning behind these results is the ZLB is an abnormal condition and future normal rates are positive. If the ZLB is anticipated to continue long into the future, then fiscal policy will be less effective. That is because households have a lower future discount rate, which increases the net present value of future tax increases and lowers the wealth gain from lower taxes today. Under extended ZLB conditions, new Keynesian models embodying the NRH should recommend fiscal policy commit to not increasing future taxes for a long time - the opposite of the current policy drive for rapid fiscal consolidation. $^{15}$

\section{Conclusion}

The paper has shown how the debate over the short-run effectiveness of fiscal policy turns on two steps: the effect of policy on $\mathrm{AD}$, and the effect of $\mathrm{AD}$ on output. The $\mathrm{NRH}$, which has shaped much of the debate surrounding bond-financed fiscal policy, concerns step 1. Because it rests on a microeconomic theory of household saving and

\footnotetext{
${ }^{15}$ The idea that the extended prospect of excess supply makes fiscal policy less effective is strange from a conventional Keynesian perspective. However, the idea of committing to not raising future taxes increases the effectiveness of fiscal policy makes a considerable sense from a Keynesian perspective which accepts the permanent income and life-cycle consumption distinction between temporary and permanent tax cuts.
} 
bequest behavior the NRH can in principle hold in all types of macro model, classical and Keynesian.

Step 2 is more fundamental and concerns whether the economy is described in classical or Keynesian terms, which determines whether there is space for output to increase in response to expansionary fiscal policy. That places macroeconomic theory at the heart of the fiscal policy debate.

The paper described six approaches to macroeconomics. The neo-Keynesian, Post Keynesian, and monetarist approaches can all be viewed as Keynesian in spirit. That is because they share a common $\mathrm{AD}$ determined approach to output determination; there is no natural level of employment and outcome to which the economy gravitates; and employment outcomes are off the labor supply schedule. Both money and bond financed fiscal policy have permanent output and employment effects in the neo-Keynesian and Post Keynesian models. However, bond financed fiscal policy has no effect in the monetarist model because of its view "money is all that matters".

The classical, new classical, and new Keynesian model can all be viewed as classical in spirit. That is because they share a classical approach to output determination and have a natural level of output and employment to which the economy gravitates. In the classical and new Keynesian models workers are always on the labor supply schedule. In the new classical model they can be off it due to price expectation errors. In the classical and new classical models discretionary fiscal policy has no effect on output and employment. In the new Keynesian model it can have temporary effects owing to price rigidities. 
Though new Keynesian models can mimic some of the effects of fiscal policy in Keynesian models, there remain profound differences. Keynesian models see the economy as capable of being persistently below full employment so that fiscal policy is persistently effective. The new Keynesian model sees the economy as returning to full employment once prices can reset so that fiscal policy is only temporarily effective and only if it is conditioned on unexpected demand shocks. That partially explains why new Keynesians want to close the budget deficit relatively quickly compared to Keynesians, showing again how theory implicates policy debate. 


\section{Appendix}

This appendix shows the comparative static predictions regarding deficit financed fiscal policy in the neo-Keynesian, Post Keynesian, monetarist, classical, new classical and new Keynesian macro models.

Table A.1. The short run economics of fiscal policy in the neo-Keynesian model.

\begin{tabular}{|c|c|c|c|c|c|}
\hline & \multicolumn{2}{|c|}{ Money financed } & \multicolumn{2}{|c|}{ Bond financed } \\
\hline & & Tax cut & Increase G & Tax cut & Increase G \\
\hline \multirow{2}{*}{$\begin{array}{l}\text { Macroeconomics } \\
\text {-Neo-Keynesian }\end{array}$} & $\begin{array}{l}\text { Imperfect } \\
\text { or no } \\
\text { NRH }\end{array}$ & $\begin{array}{l}\Delta \mathrm{y}>0 \\
\Delta \mathrm{p}>0 \\
\Delta \mathrm{i}^{>}<0 \\
\Delta \mathrm{w}=0 \\
\Delta(\mathrm{w} / \mathrm{p})<0\end{array}$ & $\begin{array}{l}\Delta \mathrm{y}>0 \\
\Delta \mathrm{p}>0 \\
\Delta \mathrm{i}^{>}<0 \\
\Delta \mathrm{w}=0 \\
\Delta(\mathrm{w} / \mathrm{p})<0\end{array}$ & $\begin{array}{l}\Delta \mathrm{y}>0 \\
\Delta \mathrm{p}>0 \\
\Delta \mathrm{i}>0 \\
\Delta \mathrm{w}=0 \\
\Delta(\mathrm{w} / \mathrm{p})<0\end{array}$ & $\begin{array}{l}\Delta \mathrm{y}>0 \\
\Delta \mathrm{p}>0 \\
\Delta \mathrm{i}>0 \\
\Delta \mathrm{w}=0 \\
\Delta(\mathrm{w} / \mathrm{p})<0\end{array}$ \\
\hline & $\begin{array}{l}\text { Perfect } \\
\text { NRH }\end{array}$ & $\begin{array}{l}\Delta \mathrm{y}>0 \\
\Delta \mathrm{p}>0 \\
\Delta \mathrm{i}^{>}<0 \\
\Delta \mathrm{w}=0 \\
\Delta(\mathrm{w} / \mathrm{p})<0\end{array}$ & $\begin{array}{l}\Delta \mathrm{y}>0 \\
\Delta \mathrm{p}>0 \\
\Delta \mathrm{i}>0 \\
\Delta \mathrm{w}=0 \\
\Delta(\mathrm{w} / \mathrm{p})<0\end{array}$ & $\begin{array}{l}\Delta \mathrm{y}=0 \\
\Delta \mathrm{p}=0 \\
\Delta \mathrm{i}=0 \\
\Delta \mathrm{w}=0 \\
\Delta(\mathrm{w} / \mathrm{p})=0\end{array}$ & $\begin{array}{l}\Delta \mathrm{y}>0 \\
\Delta \mathrm{p}>0 \\
\Delta \mathrm{i}>0 \\
\Delta \mathrm{w}=0 \\
\Delta(\mathrm{w} / \mathrm{p})<0\end{array}$ \\
\hline
\end{tabular}

Table A.2. The short run economics of fiscal policy in the Post Keynesian model.

\begin{tabular}{|c|c|c|c|c|c|}
\hline & \multicolumn{2}{|c|}{ Money financed } & \multicolumn{2}{|c|}{ Bond financed } \\
\hline & & Tax cut & Increase G & Tax cut & Increase G \\
\hline \multirow{2}{*}{$\begin{array}{l}\text { Macroeconomics } \\
\text { - Post Keynesian }\end{array}$} & $\begin{array}{l}\text { Imperfect } \\
\text { or no } \\
\text { NRH }\end{array}$ & $\begin{array}{l}\Delta \mathrm{y}>0 \\
\Delta \mathrm{p}=0 \\
\Delta \mathrm{i}=0 \\
\Delta \mathrm{w}=0 \\
\Delta(\mathrm{w} / \mathrm{p})=0\end{array}$ & $\begin{array}{l}\Delta \mathrm{y}>0 \\
\Delta \mathrm{p}=0 \\
\Delta \mathrm{i}=0 \\
\Delta \mathrm{w}=0 \\
\Delta(\mathrm{w} / \mathrm{p})=0\end{array}$ & $\begin{array}{l}\Delta \mathrm{y}>0 \\
\Delta \mathrm{p}=0 \\
\Delta \mathrm{i}=0 \\
\Delta \mathrm{w}=0 \\
\Delta(\mathrm{w} / \mathrm{p})=0\end{array}$ & $\begin{array}{l}\Delta \mathrm{y}>0 \\
\Delta \mathrm{p}=0 \\
\Delta \mathrm{i}=0 \\
\Delta \mathrm{w}=0 \\
\Delta(\mathrm{w} / \mathrm{p})=0\end{array}$ \\
\hline & $\begin{array}{l}\text { Perfect } \\
\text { NRH }\end{array}$ & $\begin{array}{l}\Delta \mathrm{y}>0 \\
\Delta \mathrm{p}=0 \\
\Delta \mathrm{i}=0 \\
\Delta \mathrm{w}=0 \\
\Delta(\mathrm{w} / \mathrm{p})=0\end{array}$ & $\begin{array}{l}\Delta \mathrm{y}>0 \\
\Delta \mathrm{p}=0 \\
\Delta \mathrm{i}=0 \\
\Delta \mathrm{w}=0 \\
\Delta(\mathrm{w} / \mathrm{p})=0\end{array}$ & $\begin{array}{l}\Delta \mathrm{y}=0 \\
\Delta \mathrm{p}=0 \\
\Delta \mathrm{i}=0 \\
\Delta \mathrm{w}=0 \\
\Delta(\mathrm{w} / \mathrm{p})=0\end{array}$ & $\begin{array}{l}\Delta \mathrm{y}>0 \\
\Delta \mathrm{p}=0 \\
\Delta \mathrm{i} \geq 0 \\
\Delta \mathrm{w}=0 \\
\Delta(\mathrm{w} / \mathrm{p})=0\end{array}$ \\
\hline
\end{tabular}


Table A.3. The short run economics of fiscal policy in the monetarist model.

\begin{tabular}{|c|c|c|c|c|c|}
\hline & & \multicolumn{2}{|c|}{ Money financed } & \multicolumn{2}{|c|}{ Bond financed } \\
\hline & & Tax cut & Increase $\mathbf{G}$ & Tax cut & Increase G \\
\hline \multirow{2}{*}{$\begin{array}{l}\text { Macroeconomics } \\
\text {-Monetarist }\end{array}$} & $\begin{array}{l}\text { Imperfect } \\
\text { or no } \\
\text { NRH }\end{array}$ & $\begin{array}{l}\Delta \mathrm{y}>0 \\
\Delta \mathrm{p}>0 \\
\Delta \mathrm{i}^{>}<0 \\
\Delta \mathrm{w}=0 \\
\Delta(\mathrm{w} / \mathrm{p})<0\end{array}$ & $\begin{array}{l}\Delta \mathrm{y}>0 \\
\Delta \mathrm{p}>0 \\
\Delta \mathrm{i}>0 \\
\Delta \mathrm{w}=0 \\
\Delta(\mathrm{w} / \mathrm{p})<0\end{array}$ & $\begin{array}{l}\Delta \mathrm{y}=0 \\
\Delta \mathrm{p}=0 \\
\Delta \mathrm{i}>0 \\
\Delta \mathrm{w}=0 \\
\Delta(\mathrm{w} / \mathrm{p})=0\end{array}$ & $\begin{array}{l}\Delta \mathrm{y}=0 \\
\Delta \mathrm{p}=0 \\
\Delta \mathrm{i}>0 \\
\Delta \mathrm{w}=0 \\
\Delta(\mathrm{w} / \mathrm{p})=0\end{array}$ \\
\hline & $\begin{array}{l} \\
\text { Perfect } \\
\text { NRH }\end{array}$ & $\begin{array}{l}\Delta \mathrm{y}>0 \\
\Delta \mathrm{p}>0 \\
\Delta \mathrm{i}^{>}<0 \\
\Delta \mathrm{w}=0 \\
\Delta(\mathrm{w} / \mathrm{p})<0\end{array}$ & $\begin{array}{l}\Delta \mathrm{y}>0 \\
\Delta \mathrm{p}>0 \\
\Delta \mathrm{i}^{>}<0 \\
\Delta \mathrm{w}=0 \\
\Delta(\mathrm{w} / \mathrm{p})<0\end{array}$ & $\begin{array}{l}\Delta \mathrm{y}=0 \\
\Delta \mathrm{p}=0 \\
\Delta \mathrm{i}=0 \\
\Delta \mathrm{w}=0 \\
\Delta(\mathrm{w} / \mathrm{p})=0\end{array}$ & $\begin{array}{l}\Delta \mathrm{y}=0 \\
\Delta \mathrm{p}=0 \\
\Delta \mathrm{i}>0 \\
\Delta \mathrm{w}=0 \\
\Delta(\mathrm{w} / \mathrm{p})=0\end{array}$ \\
\hline
\end{tabular}

Table A.4. The short run economics of fiscal policy in the classical model.

\begin{tabular}{|c|c|c|c|c|c|}
\hline & & \multicolumn{2}{|c|}{ Money financed } & \multicolumn{2}{|c|}{ Bond financed } \\
\hline & & Tax cut & Increase G & Tax cut & Increase G \\
\hline \multirow{2}{*}{$\begin{array}{l}\text { Macroeconomics } \\
\text { - Classical }\end{array}$} & $\begin{array}{l}\text { Imperfect } \\
\text { or no } \\
\text { NRH }\end{array}$ & $\begin{array}{l}\Delta \mathrm{y}=0 \\
\Delta \mathrm{p}>0 \\
\Delta \mathrm{i}>0 \\
\Delta \mathrm{w}>0 \\
\Delta(\mathrm{w} / \mathrm{p})=0\end{array}$ & $\begin{array}{l}\Delta \mathrm{y}>0 \\
\Delta \mathrm{p}>0 \\
\Delta \mathrm{i}>0 \\
\Delta \mathrm{w}>0 \\
\Delta(\mathrm{w} / \mathrm{p})=0\end{array}$ & $\begin{array}{l}\Delta \mathrm{y}=0 \\
\Delta \mathrm{p}=0 \\
\Delta \mathrm{i}>0 \\
\Delta \mathrm{w}=0 \\
\Delta(\mathrm{w} / \mathrm{p})=0\end{array}$ & $\begin{array}{l}\Delta \mathrm{y}=0 \\
\Delta \mathrm{p}=0 \\
\Delta \mathrm{i}>0 \\
\Delta \mathrm{w}=0 \\
\Delta(\mathrm{w} / \mathrm{p})=0\end{array}$ \\
\hline & $\begin{array}{l}\text { Perfect } \\
\text { NRH }\end{array}$ & $\begin{array}{l}\Delta \mathrm{y}=0 \\
\Delta \mathrm{p}>0 \\
\Delta \mathrm{i}>0 \\
\Delta \mathrm{w}>0 \\
\Delta(\mathrm{w} / \mathrm{p})=0\end{array}$ & $\begin{array}{l}\Delta \mathrm{y}>0 \\
\Delta \mathrm{p}>0 \\
\Delta \mathrm{i}>0 \\
\Delta \mathrm{w}=0 \\
\Delta(\mathrm{w} / \mathrm{p})=0\end{array}$ & $\begin{array}{l}\Delta \mathrm{y}=0 \\
\Delta \mathrm{p}=0 \\
\Delta \mathrm{i}=0 \\
\Delta \mathrm{w}=0 \\
\Delta(\mathrm{w} / \mathrm{p})=0\end{array}$ & $\begin{array}{l}\Delta \mathrm{y}=0 \\
\Delta \mathrm{p}>0 \\
\Delta \mathrm{i}>0 \\
\Delta \mathrm{w}>0 \\
\Delta(\mathrm{w} / \mathrm{p})=0\end{array}$ \\
\hline
\end{tabular}

Table A.5. The short run economics of fiscal policy in the new Keynesian model.

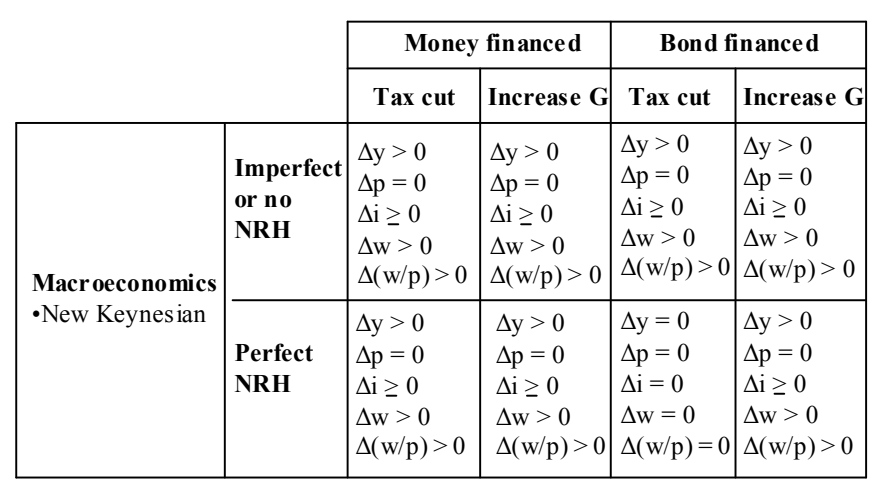




\section{References}

Aschauer, D.A., "Is Public Expenditure Productive?" Journal of Monetary Economics, 23 (1989), $177-200$.

Barro, R.J., "Are government bonds net wealth?” Journal of Political Economy, 82 (1974), $1095-1117$.

Bhatta, S.D., and Drennan, M.P., "The economic benefits of public investment in transportation: A review of the recent literature," Journal of Planning and Education Research, 22 (2003), p.288-296.

Blinder, A.S., and Solow, R., "Does Fiscal Policy Matter?" Journal of Public Economics, 2 (4) (November 1973), 319 - 337.

Christ, C.F., "A simple macroeconomic model with a government budget restraint," Journal of Political Economy, 76 (1968), 53 - 67.

Christiano, L., M. Eichenbaum, and S. Rebelo, "When is the government spending multiplier large?” NBER working paper 15394, October 2009.

Dullien, S., "The new consensus from a traditional Keynesian and Post Keynesian perspective: A worthwhile foundation for research or just a waste of time?" Economie Appliquee, LXIV (1) (2011), 173 - 200.

Dutt A.K., "Wage rigidity and unemployment: The simple diagramatics of two views," Journal of Post Keynesian Economics, 9 (1986/7), 279 - 90.

Friedman, M., "The lag in effects of monetary policy," Journal of Political Economy, 69 (October), 1961, 447 - 466.

-17 .

-, “The role of monetary policy,” American Economic Review, 58 (1968), 1

-------, "A theoretical framework for monetary analysis," Journal of Political Economy, 78 (1970), 193 - 238.

Godley, W. and M. Lavoie, Monetary Economics: An Integrated Approach to Credit, Money, Income, Production and Wealth, London: Palgrave/Macmillan, 2007.

Keynes, J. M., The General Theory of Employment, Interest, and Money, London: Macmillan, 1936.

Lucas, R.E. Jr., "Some international evidence on output - inflation trade-offs," American Economic Review, LXIII (3) (1973), 326 - 334. 
McCallum, B.T. and Whitaker, J.K., "The effectiveness of fiscal feedback rules and automatic stabilizers under rational expectations," Journal of Monetary Economics, 5 (1979), $171-186$.

Moore, B.J., Horizontalists and Verticalists: The Macroeconomics of Credit Money, Cambridge: Cambridge University Press, 1988.

Munnell, A.H., "Why has Productivity Growth Declined? Productivity and Public Investment," New England Economic Review, January/February 1990, 4 - 22.

Palley, T. I., "Optimal monetary policy in the presence of a monetarist transmission mechanism," Economics Letters, 55 (1997), 109-14.

Reinhart, C.M. and K.S. Rogoff, "This time is different: A panoramic view of eight centuries of financial,” NBER working paper No.13882, March 2008.

Rotemberg, J.J., "The new Keynesian microfoundations," NBER Macroeconomics Annual, 1987, 69 - 104.

Sargent, T.J., Macroeconomic Theory, New York: Academic Press, 1979.

Tobin, J., "Money, capital, and other stores of value," American Economic Review, 51 (1961), $26-37$.

-----------, "A general equilibrium approach to monetary theory," Journal of Money, Credit and Banking, 1 (1969), 15- 29.

-----------, "Money and finance in the macroeconomic process," Journal of Money, Credit and Banking, 14 (1982), 171 - 204.

Tobin, J. and W.H. Buiter, "Long run effects of fiscal and monetary policy on aggregate demand," in J.L. Stein (ed.), Monetarism, Amsterdam: North Holland, 1976. 
Publisher: Hans-Böckler-Stiftung, Hans-Böckler-Str. 39, 40476 Düsseldorf, Germany Phone: +49-211-7778-331, IMK@boeckler.de, http://www.imk-boeckler.de

IMK Working Paper is an online publication series available at: http://www.boeckler.de/imk 5016.htm

ISSN: $1861-2199$

The views expressed in this paper do not necessarily reflect those of the IMK or the Hans-Böckler-Foundation.

All rights reserved. Reproduction for educational and non-commercial purposes is permitted provided that the source is acknowledged. 